\title{
SUCCESS FACTORS OF PROFESSIONAL TRANSFORMATION FROM FISHERMEN TO TOURISM MANAGERS IN BANGSRING VILLAGE OF WONGSOREJO DISTRICT, BANYUWANGI REGENCY, EAST JAVA, INDONESIA
}

\author{
Margiono Mohamad Regalfa*, Lestari Eny, Anantanyu Sapja \\ University of Sebelas Maret, Surakarta, Indonesia \\ *E-mail: mohamadregalfa@gmail.com
}

\begin{abstract}
For a long time, fishermen in Bangsring Village were fishing using chemicals such as potassium cyanide and bombs. As a result of the use of these materials, making the marine ecosystem severely damaged. The condition of the destruction of coral reefs has made fish in the Strait of Bali disappear. Damage to the ecosystem has a negative impact on the catches of the fishermen, so that their income has decreased. The main way to resolve the ecosystem crisis in the waters of the Bali Strait is to carry out coral reef conservation. Underwater ecosystem conservation conducted by the fishermen has a positive impact. Now the fishermen abandon bad habits in catching fish, even leaving their fishing profession and turning into tourism managers. This study aims to describe the factors that led to the successful transformation of the profession from fishermen to tourism managers. This research uses descriptive qualitative method. Data collection is done by direct observation, interviews, and document review. The results of this study found that the success factors of transformation from fishermen to tourism managers were influenced by two factors. First, the weakness factor of being a fisherman consists of a decrease in fish catch, erratic income, lack of guarantees at work, and uncertain working time. Second, the new opportunity factor in the world of tourism which consists of a concert area in the Bali Strait, an increase in the world of tourism, in Banyuwangi, employment guarantees, and definite income. The factors that have occurred have succeeded in transforming the profession of the fishing community into a tourism manager.
\end{abstract}

\section{KEY WORDS}

Success factors, transformation of profession, Bangsring fishermen, tourism managers.

The goal of the Sustainable Development Goals (SDG's) in 2030 is to increase economic benefits for developing island nations and less developed countries from the sustainable use of marine resources, including through sustainable management of fisheries, aquaculture, and aquatic tourism. The sea area of the Banyuwangi Regency is a strategic area because of its location which is the connecting point between the regions on the island of Java and the island of Bali. The potential of fisheries in Banyuwangi Regency is very numerous and varied. However, this coral reef damage actually occurred in the Bali Strait area, precisely located in the Bangsring Village area, Wongsorejo District. It turned out that the fishermen in this village had been fishing using chemicals such as potassium cyanide and bombs. The activity has been carried out for decades. The destruction of the underwater ecosystem has resulted in the loss of the presence of fish caught by fishermen so far, and this automatically has an impact on the low income of fishermen.

Damage to the underwater ecosystem that occurred in the Bali Strait made Ihwan Arif, the son of a senior fisherman in Bangsring Village aware to improve the coral reef ecosystem. Ihwan Arif invited the fishermen to jointly stop fishing with chemicals and carry out rehabilitation of the underwater ecosystem on the Bangsring beach. However, his invitation was strongly opposed by the fishermen in his village. The fishermen who refused the invitation argued that the way they had done so far was a hereditary tradition and had to be preserved. However, with the persistence of Ihwan Arif and his colleagues who carried out coral rehabilitation in the Bali strait, began to bear fruit. Now, fishermen realize how important it is to protect the environment. The rehabilitation carried out by Bangsring 
fishermen is not only done on the water side, but also on the land side, namely by planting sea cypress trees on the Bangsring beach. Rehabilitation is also ongoing, currently there is one floating house and 500 fish apartments in an area of 15 hectares. As for on land, the planting of sea cypress is also expanded on the south coast side from what was originally only in the north. The existence of a floating house as a place to rehabilitate ornamental fish and sharks that were accidentally caught by fishing nets is an attraction for the community. Over time, coral reefs and fish returned to normal in the waters of Bangsring Village. Not only local residents who then enjoy the beauty of the underwater, but also residents from outside the area and even foreign tourists.

\section{METHODS OF RESEARCH}

Research on Success Factors for Professional Transformation from Fishermen to Tourism Managers uses descriptive qualitative methods. The reason for adjusting qualitative methods is easier when dealing with plural reality. This method presents directly the nature of the relationship between researchers and respondents. In addition, this method is more sensitive and more adaptable to the many sharpening of the mutual influence on the patterns of values encountered (Moleong). Data collected in this study are data obtained in the field from informants and observations from researchers. Data collection techniques used are direct observation, semi-structured interviews, and document review. This study uses technical triangulation, which is to test the validity of the data carried out by checking the data to the same source with different techniques. This analysis technique refers to Miles \& Huberman (in Salim, 2006) which states the components in data analysis, namely reduction, presentation of data, and drawing conclusions.

\section{RESULTS AND DISCUSSION}

Bangsring Village is one of the villages in Wongsorejo District, Banyuwangi Regency, East Java, which is located on the east coast of Java with an area of $55.26 \mathrm{KM}$.

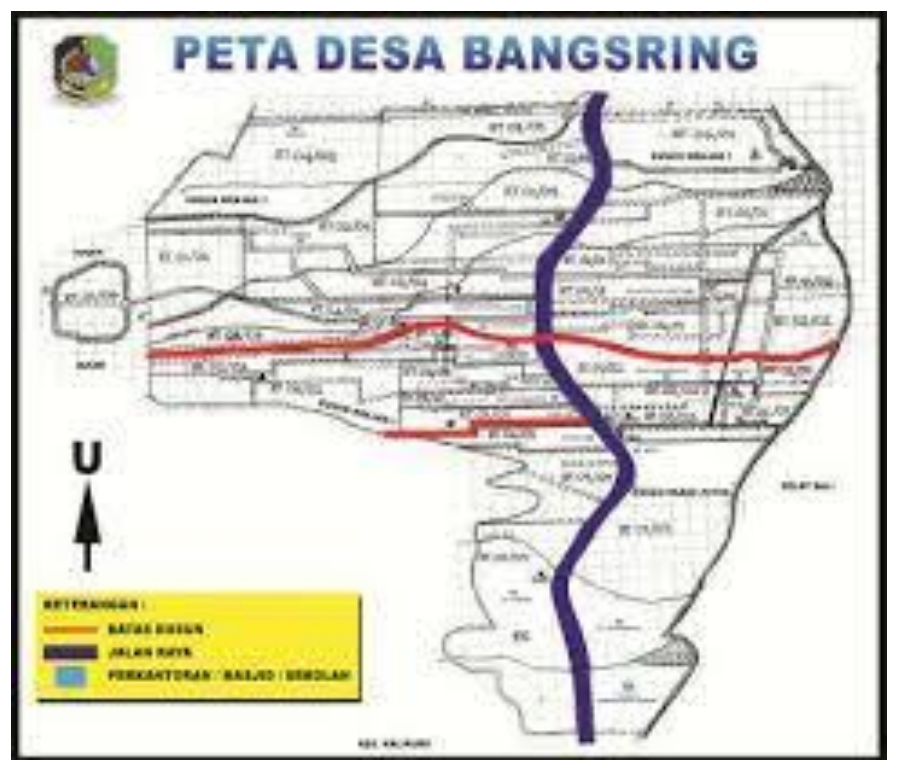

Figure 1 - Map of the village area of Bangsring (Source: Bangsring village profile)

Bangsring Village is located in a very strategic area, which is on the main route of Surabaya-Banyuwangi. The distance from the capital city of Banyuwangi is around $25 \mathrm{KM}$. Bangsring village had a population of 5,078 people as of September 2019. It consisted of 2,371 male residents and 2,707 female residents with a density of 110 people per square kilometer. 
Table 1 - Population Profile of Bangsring Village

\begin{tabular}{|c|c|c|c|c|}
\hline \multirow{2}{*}{ No } & \multirow{2}{*}{ Description } & \multicolumn{3}{|c|}{ Total } \\
\cline { 3 - 5 } & & $\mathrm{M}$ & $\mathrm{F}$ & $\mathrm{M}+\mathrm{F}$ \\
\hline 1 & Population earlier this month & 2.371 & 2.707 & 5.078 \\
\hline 2 & Born & 0 & 1 & 1 \\
\hline 3 & Dead & 0 & 2 & 2 \\
\hline 4 & Newcomer & 4 & 3 & 6 \\
\hline 5 & Homesteader & 2.370 & 2.708 & 5 \\
\hline 6 & Residents later this month & & 1 & 5.078 \\
\hline
\end{tabular}

Source: Bangsring village profile.

Previously, Bangsring Village was a producer of ornamental fish. But in the 1960 s to 1970s there was damage to the underwater ecosystem caused by fishermen who were accustomed to catching fish with potassium and bombs. This condition lasted until 2005. The damage to the ecosystem that occurred at that time was due to the wrong fishing process by the fishermen. As a result, Bangsring fishermen have difficulty catching fish and their income has dropped dramatically.

At that time, Mr. Ihwan Arif, who was the son of a senior fisherman in Bangsring Village, invited the fishermen to stop using chemicals in fishing. Changing the mindset about the importance of protecting marine ecosystems is a basic strategy for making fishermen aware even though it is not easy. It takes time, energy, thoughts and feelings to deal with the intimidation of the fishermen who refuse the invitation to conserve coral reefs. In fact, some fishermen reject it by giving threats.

"We were opposed by the fishermen here. Including my father who also opposed strongly. My determination is to make up for our mistakes, the fishermen who used to destroy nature until the fish were all gone. But it is not easy. We are hated by fishermen, even to the point where they sprinkle poison on the beach sand so that we stop taking action (for conservation). Yes, it's all because they do not fully understand what we mean, do not yet understand about the meaning of conservation which will later benefit us, right? The point is in communication to wake up. It takes an extra approach and also time. "(Interview with Mr. Ihwan Arif, September 25th 2019).

Various methods are used, including approaching religious leaders to fill in the Koran recitation and sermon on Friday praying using materials about environmental awareness. Slowly, the effort to awaken fishermen in saving the sea is bearing fruit. The fishermen gradually began to abandon the tradition of fishing with chemicals and to conserve the underwater ecosystem. In 2014, the Ministry of Maritime Affairs and Fisheries of the Republic of Indonesia provided assistance in the form of floating houses which were used as monitoring of underwater ecosystems, motorized boats, and buoys. Over the years of carrying out conservation, the condition of coral reefs began to improve and attract the attention of the public to see it directly. Gradually, now, the conservation area becomes crowded with tourist visits.

"The condition of the underwater world which is gradually improving, the fish returning, the coral reefs that we plant are growing well, all the results of our struggle to conserve. Support also continues to come, Banyuwangi district government that supports tourism, promoting. From the Ministry of Maritime Affairs and Fisheries who have provided assistance in the form of floating homes for fish conservation, and also canoes for tourism. And many supportive environmental communities. There are many programs from TV stations shooting here, all of which are involved in spreading information about us (Bangsring Underwater) to the world." (Interview with Mr. Ihwan Arif, September 25th 2019).

Over time, Bansring beach visitors are increasing in number. This is inseparable from the promotion of tourism efforts. The large number of television programs that broadcast coverage on conservation and educational tourism in Bangsring also influenced the increase in the number of visitors.

Economic factors, social factors, land conditions factors and government regulations together have a positive influence on decisions (Bayu Setyoko, 2014). When seen, the 
transfer of profession carried out by fishermen in the village of Bangsing is influenced by several factors as above, namely related to the condition of the land to catch fish that have been destroyed and the existence of a conservation area determined by the fishermen group Samudra Bhakti with the Banyuwangi district government contained in Regional Regulation No. 8 of 2012 concerning regional planning and spatial planning for 2012-2032.

Based on the theory used in this study, namely from Albert Bandura (2002) which states that behavior can be influenced by the interaction of 3 determinants namely personal factors: self-efficacy (trust in personal ability to resolve behavior correctly), behavior factors: response individuals to carry out a behavior and environmental factors: environmental aspects or rules that affect individuals in the success of changing behavior, where all three factors have a causal relationship. Based on the Bandura theory, the results are obtained that there are factors as follows.

Switching professions carried out by the community is not without cause. The changes were made with a better hope than before. The fishing community in the village of Bangsring, Wongsorejo, Banyuwangi is one of them. In the past, the Bangsring beach area was one of the fish-producing areas in Banyuwangi. The condition of its waters is sustainable, making Bangsring waters become the largest ornamental fish producing area in Banyuwangi. The ornamental fish caught by Bangsring fishermen is sent to various regions in Indonesia. However, the underwater ecosystem in the Bali Strait has been damaged by the use of chemicals in fishing. The condition of the damage to the underwater ecosystem affects the fish catch and income of the fishermen.

There are several factors that are able to influence the fishermen in Bangsring village to switch professions from fishermen to tourism actors.

Various factors that influence fishermen switch professions include declining fish catch, uncertain and declining income, lack of guarantees at work, uncertain working time and reduced fishing area.

The first factor is the decrease in fish catch. The decline in fish catches of Bangsring village fishermen is caused by damage to coral reefs. Coral reefs are home and a source of food for fish, if coral reefs die and are destroyed, automatically the existence of fish will decrease and move to other places. Damage to coral reefs in the waters of the village of Bangsring caused by the use of chemicals made by fishermen in fishing.

Uncertain income. The decline in fish catches has an effect on the income of fishermen. This erratic income makes fishermen unable to meet their daily needs, and it is also not uncommon for fishermen to lend money to moneylenders to meet their needs.

Previously my income was small, around Rp. 30,000 - Rp. 50,000 per day, paid every three days, with uncertain working hours. (Interview with Mr. Fauzan, September 26th, 2019).

There is no guarantee in working. Being a freelance fisherman is not easy and must be independent. All risks that occur when working in the ocean make fishermen are required to be skilled in handling them independently. The existence of such a large risk is not accompanied by a guarantee of safety at work. So, if something bad happens while working, they will bear it themselves. This has become a burden for fishermen because they have to pay more.

"In the past there was nothing. No one is given anything other than the salary given once every 3 days; it's just that most are given groceries just before Eid. There is no guarantee of anything ". (Interview with Mr. Fauzan, September 26th, 2019).

"Because it was counted as a freelance worker, so there was no guarantee of employment." (Interview with Mr. Zurik, September 24th, 2019).

Uncertain work time and reduced fishing area. In addition to weather factors that are sometimes erratic and affect shipping, work hours are also different. The fishermen set sail in the afternoon and return ashore the next day. This is because the fishermen are looking for fish in the ocean sea far away from land or coastal areas.

"Uncertain work time. Do not have certainty from 7 am to evening, sometimes also until midnight. Sometimes I am also called suddenly because there are fish that come in time to enter the warehouse. Before that, I also worked for fishing but in the waters of Muncar and 
southern Banyuwangi. It was very far from home, left at night, came home during the day, at that time the results were pretty good, but because my body was not strong because I had to be constantly exposed to the wind on the road, far away, not to mention the midnight wind, on the beach too, finally I worked at Mr. Ihwan Arif's father's place. " (Interview with Mr. Fauzan, September 26th, 2019).

The decline in fish catches and economic conditions experienced by people who work as fishermen have a direct impact on income. In the condition of the destruction of the marine ecosystem that occurred at that time, there emerged a conservation movement to improve the underwater ecosystem. Over time and efforts to conserve coral reefs that have increased, finally able to make the fish come again in the waters of the Bali strait. Gradually, the Bangsring beach area began to be glimpsed by tourists because of its underwater charm that began to improve. Until finally, the Bangsring beach area became a famous tourist destination in the Banyuwangi district. Some opportunities are offered by the world of tourism on the Bangsring beach that can attract the attention of fishermen to switch professions.

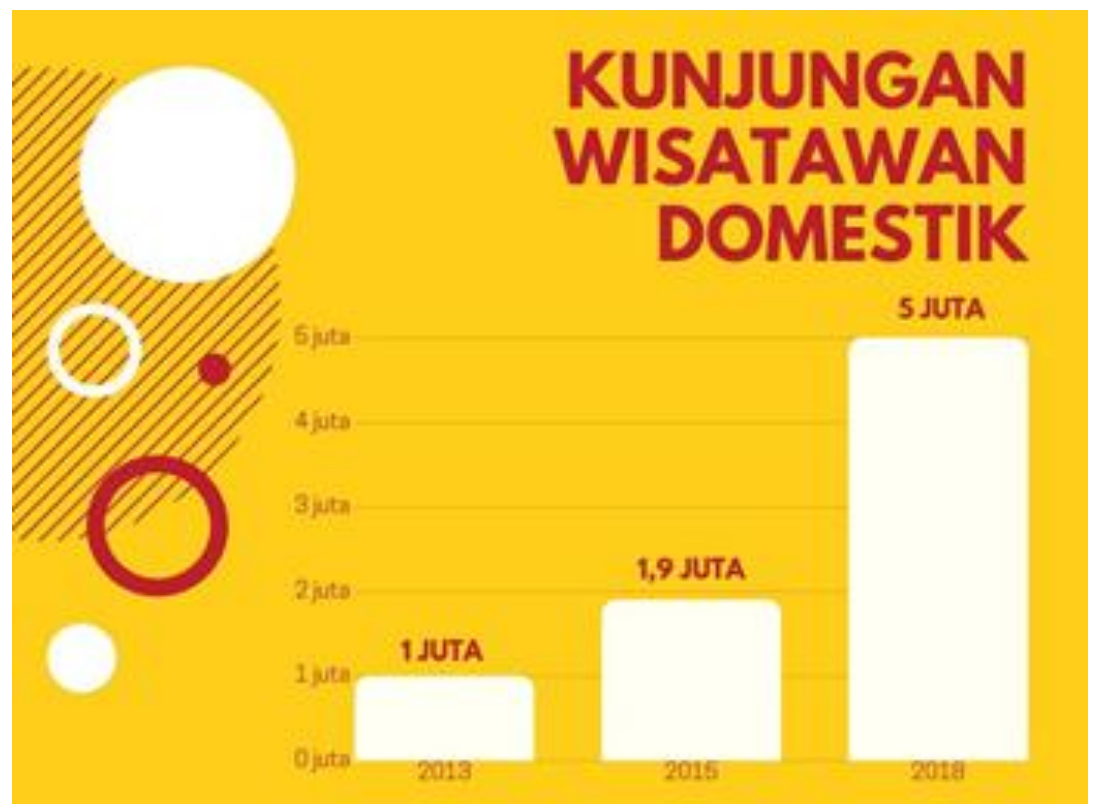

Figure 2 - Domestic Tourist Visits Chart at Banyuwangi (Source: www.banyuwangikab.go.id)

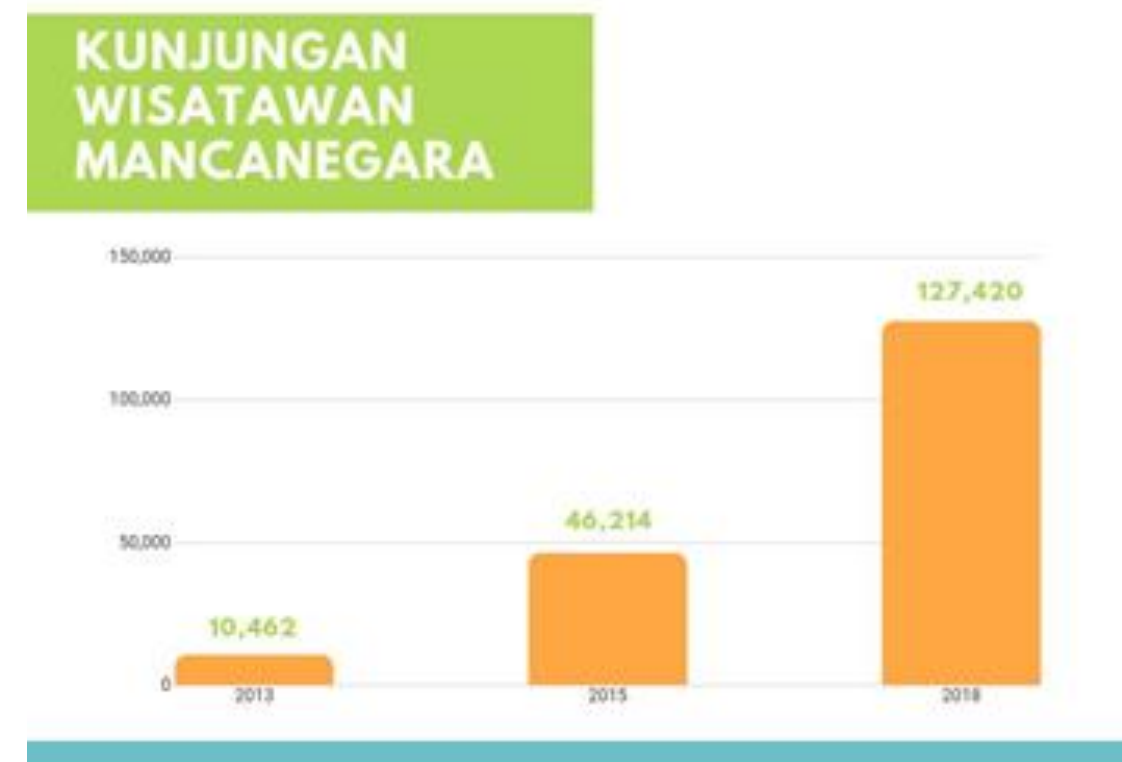

Figure 3 - Graph of Overseas Tourist Visits in Banyuwangi (Source: www.banyuwangikab.go.id) 
The Bangsring waters area, which suffered an area of 88.23 ha, caused a group of fishermen from Samudra Bhakti together with the Banyuwangi district government to make the Bangsring beach a Joint Maintenance Zone (ZPB) which was made as Regional Regulation No. 8 of 2012 concerning regional planning and spatial planning for 2012-2032. ZPB area is an area that is free from exploitation activities, so that anyone is prohibited from carrying out exploitation activities. As a result, fishermen look for fish in other areas far away. The far fishing area, does not guarantee the results obtained, it is not uncommon for fishermen to get a small yield and make a loss. This factor ultimately led them to choose to join the Samudra Bhakti fishermen group to participate in preserving the environment, even though they refused.

In 2011, the world of tourism in the Banyuwangi regency began to rise. Supporting infrastructure for tourism and industry began to be built. The route to the main destination in the Banyuwangi district has been improved. Banyuwangi's native culture-based festival and regular sports are held every month of the year to attract tourists from home and abroad.

The development is carried out in supporting destinations around the well-known main destinations, such as ljen Crater and Alas Purwo and Baluran National Parks. One of the favorite destination destinations is Bangsring Underwater. This relatively new destination was able to bring in local tourists even from abroad. The number of tourists who come to the Underwater Bangsring is what makes the fishermen who were experiencing a decrease in income to be interested in joining.

"I used to be an ornamental fish fisherman, already from 2008. Starting from planting coral, ...Once an ornamental fish fisherman, now here (working in the Underwater Bangsring). " (Interview with Mr. Zurik, September 24th, 2019).

One of the considerations of fishermen to change their profession to become tourism actors is the provision of facilities and legal protection. As stated by Mr. Sukir in the following interview:

"We facilitate the fishermen and we train ourselves, free from extortion and receive legal protection. Thanks to this existence, many fishermen joined in. " (Interview with Mr. Sukir on 25th September 2019).

In the past, fishermen in the village of Bangsring were often hit by raids by the Indonesian Navy on patrol while sailing. Generally, fishermen are found carrying potassium cyanide and fish bombs while sailing. In addition, because of the limited knowledge to obtain a permit to catch ornamental fish, the fishermen also always go through brokers. So they have to pay dearly to take care of the documents needed. On the other hand, the fishing group Samudra Bhakti offers facilities to help the fishermen. Even the fishermen also received training on conservation and fishing in an environmentally friendly way.

The income of the nalayan people who now work as tour operators in the Bangsring Underwater has stabilized. They feel the stability of this income after joining and working as tourism agents rather than when they were fishermen. This was acknowledged directly by them, as in the following interview:

"Here payment is made once a week, Rp. 50,000 per normal day, if the red week and date, it increases to Rp. 100,000. " (Interview with Mr. Zurik, September 24, 2019).

"Now here every day the payment is Rp. 50,000 for a normal day, but if Sunday and holiday can be Rp. 100,000 per day. Food is also given here, not bought, already provided. The hour is also clear from seven in the morning until five in the afternoon, close to family, if you rest you can go home because it's close " (Interview with Mr. Fauzan, September 26th, 2019).

In addition to stable income, there are several factors such as lunch that is borne every day, making it an attraction for workers. In addition, the proximity of the workplace to home also makes added value for workers, as stated by Mr. Fauzan in the interview above. Now, people who used to work as fishermen have turned into tourism managers. They currently work according to their skills as fishermen. That is, their expertise as fishermen who are good at sea, now they work as drivers of tourist ships that take tourists sailing to floating homes and the island of Tabuhan. Those who used to be good at diving while fishing, are now guides for tourists who want to snorkel and dive in Bangsring. 


\section{CONCLUSION}

Based on the discussion of the results of this study, there are two factors occurring professional transformation experienced by the fishermen of Bangsring Village, Wongsorejo District, Banyuwangi Regency which are now tourism managers. The first factor is the weakness of being a fisherman, namely: a decrease in fish catches, then directly impacting declining income as well, there is no guarantee of work as a fisherman whose work is very hard and high risk, and uncertain working time. The second factor is the existence of new opportunities in the world of tourism which consist of the existence of conservation areas in the Bali Strait, the increasing world of tourism in Banyuwangi, the existence of guaranteed employment, and definite income. These opportunities are the success of good ecosystem conservation, the development of the world of tourism in Banyuwangi which also impacts on tourism in his village, obtaining a definite income, and obtaining work safety guarantees.

\section{REFERENCES}

1. Amri, Faktor-Faktor Yang Mempengaruhi Alih Profesi Masyarakat Nelayan di Kota Bengkulu 2015.

2. Muslim Aziz, Pendekatan Partisipatif dalam Pemberdayaan Masyarakat Yogyakarta. Jurnal UIN vol. 8, No.2, 2007

3. Karsidi Ravik, Kajian Keberhasilan Transformasi Pekerjaan Dari Petani ke Pengrajin Industri Kecil, 1999.

4. Lexy J Moleong, Metodologi Penelitian Kualitatif Edisi Revisi, PT Remaja Rosdakarya, Bandung 2014.

5. Mardikanto Totok, Pemberdayaan Masyarakat, Alfabeta Bandung 2015.

6. Salim, Agus, Teori dan Paradigma Penelitian Sosial: Buku Sumber Untuk Penelitian Kualitatif, Tiara Wacana, Yogyakarta 2006. 